\title{
A Study on the Development Environment and Countermeasures of Cruise Tourism in Tianjin City
}

\author{
Hongsheng Zhang ${ }^{1, \text { a }}$ \\ ${ }^{1}$ Tianjin Maritime College, Tianjin City, 300350, China
}

Keywords: Tianjin city; Cruise tourism; Development environment; Development strategy

\begin{abstract}
In recent years, with the continuous improvement of people's economic level, cruise tourism has attracted more and more attention. As cruise tourism has a high multiplier effect, some qualified port cities have proposed strategies to develop cruise tourism. As one of the important ports in China, Tianjin is located in the heartland of the Bohai economic zone, and it has the unique advantages for developing cruise tourism. Based on the author's learning and practical experience, this paper firstly analyzed the development environment of cruise tourism in Tianjin, and then put forward the development strategy of Tianjin cruise tourism.
\end{abstract}

\section{Introduction}

Since 1980s, cruise ships have gradually docked in China. Although the cruise tourism in China started late, it has developed rapidly with great potential. With the sustained and rapid development of China's economy and the continuous improvement of people's living standards and the increasing consumption of tourism, cruise tourism will become one of the major tourism options for the Chinese people. At the same time, the traditional market of international cruise tourism has become more and more mature, and it is necessary to find new space for development. As one of the important coastal port cities in china, the prospect of developing cruise tourism in Tianjin is very good. If we can carefully cultivate cruise tourism market and develop cruise economy, Tianjin's new economic growth point will be formed.

\section{The Cruise Tourism Development Environment in Tianjin}

The strengths of the cruise tourism development in Tianjin. Firstly, it has unique geographical strength. Tianjin is located in the center of Bohai economic circle, and occupies the center of Northeast Asia. As the nearest port city from Beijing, the concept of "city of the world" developed jointly by "Jing" and "Jin", and the concept of "world city" has long been demonstrated by experts. With the development and opening of Binhai New Area getting into the overall development strategy of the country and as the gateway to the opening of the north, the establishment and implementation of the functional positioning of the north international shipping center and the international logistics center, Tianjin is inevitable to lead to the upsurge of international inbound and cruise tourism accompanied by the raising attention from the world. Secondly, it boasts high quality and perfect port construction. The northern port area of Tianjin port has a large scale and more advanced marine passenger station, which basically forms two regular and irregular cruise routes along the coast and the international districts. In June 2010, Tianjin Dongjiang Bonded Zone international cruise home port terminal will be completed and put into use. The quay has a length of 625 meters, which can be used by two large luxury cruise ships. The capacity of Tianjin port for receiving international luxury cruise ships will continue to increase, and cruise tourism is bound to show a good development. Thirdly, it has relatively rich tourism resources. Tianjin not only has a variety of natural tourism resources, but also gives birth to a broad and profound human tourism resources. With the increasingly convenient transportation in Beijing and Tianjin, the effect of the city of Beijing and Tianjin is gradually clear, and the two metropolis tourism will become a win-win situation in which domestic resources and resources complement each other, tourist groups flow together, and domestic and international markets open up together. 
The weaknesses on Tianjin cruise tour development. Firstly, the development of cruise industry started relatively late. With the development of cruise economy, the main ports in China have the idea of developing cruise tourism. However, Tianjin started late in this area, and the development of related industries is weak. According to the relevant research reports, Tianjin cruise industry related economic assessment ranked lowest among Shanghai, Ningbo, Dalian, Qingdao, Tianjin and other cities, which thus restricted the development of Tianjin cruise tourism market. Secondly, the tourist service facilities of cruise lines are insufficient. International cruise economy agglomeration characteristics require that the shopping, catering and hotel facilities of the cruise service should concentrate on the surrounding place of the cruise home port. Tianjin hotels and entertainment and cultural facilities are mostly concentrated on the development zone. Tanggu's tourist service facilities are relatively backward in terms of quantity and service level. After completion of the Tianjin international cruise home port, the establishment of supporting facilities are yet to be built. Judging from the current situation, it is still difficult to meet the requirements of developing international cruise tourism. Thirdly, it is lack of professional service personnel for cruise ships. Many colleges and universities in China are equipped with tourism or hotel management professional, but specialized cruise tourism talent education is very few. Although the construction of Tianjin cruise personnel training base has become a consensus among the government, enterprises and educational institutions, only the Tianjin Ocean Shipping and Vocational Academy opened professions of the cruise crew. Thus, the education of professional service personnel in cruise needs to be strengthened urgently.

The opportunities for Tianjin cruise tourism development. Firstly, there is a huge market for cruise tourism. According to the China Association of transportation passenger liner branch forecast, the number of outbound tourists will increase by 12.5 percent annually in the next 15 years, and the development of the cruise industry will meet this requirement; in 2004, China's cruise reception revenue is about 240 million US dollars, accounting for only $1.3 \%$ of the world's total industry revenue, and there is still a huge market to be developed. At present, Tianjin cruise tour is still having very large space. If visitors to port can make a short sightseeing tour in Tianjin, they will obviously promote the development of tourism, especially the development of catering, entertainment and other industries. Secondly, the state has made great efforts to develop cruise economy. In June 2008, the National Development and Reform Commission issued the guiding opinions on Promoting the Development of China's Cruise Industry. From the macro point of view, it initially defines the guiding ideology, overall goals and main tasks of the development of China's cruise industry. The National Development and Reform Commission is taking the lead in proposing the economic development plan and relevant policies and regulations of China's cruise ships; border inspection has taken some effective measures, such as entrance procedures with the ship, wheel advance inspection going to the anchorage destination and so on, which facilitates the entry and exit of the cruise line. The state's support for the cruise industry economy will inevitably lead to the development of cruise tourism market.

The threats for Tianjin cruise tourism development. Firstly, there are competitions in the surrounding port cities. At present, China has three cruise ports with complete facilities, including Shanghai, Xiamen, Sanya and Phoenix Island International Passenger Transportation Center. In addition, the Dalian international cruise terminal has entered the design phase, and cities such as Qingdao are planning or building a cruise terminal. If Tianjin can't provide good conditions for cruise ships, they will probably choose other cities, such as Qingdao, Dalian, etc. In the face of domestic south and north and adjacent port attack, Tianjin port must strengthen its competitiveness from the improvement of soft and hardware facilities. Secondly, there are competitions in other regions of the Asia Pacific. China's cruise market share in the global cruise market share is low. However, many countries or regions begin earlier than China's cruise economy, and have more experience than China. The Asian cruise market is divided into two regions: the Far East and Southeast Asia. The Far East has competition from South Korea and Japan, while Southeast Asia has competition from Singapore, Thailand, Vietnam and Malaysia. The Asian cruise market has become a a hotly contested spot. The development of cruise economy in Tianjin and the 
development of cruise tourism market are imperative, and the sooner is the better.

\section{The Strategies for Tianjin Cruise Tourism Development}

Strengthen surrounding regional cooperation. Cruise city construction must rely on the resources of the surrounding areas and jointly develop cruise tourism market. Tianjin should give full play to its regional advantages and actively build a Bohai Bay Cruise area, including Beijing, Hebei, Shandong and Liaoning. This will help make full use of the rich tourist resources and reception facilities throughout the country and attract more tourists, so as to promote Tianjin to embark on the fast track of cruise tourism development.

Attract international cruise company. Construction of cruise terminals and ancillary facilities is usually huge on the investment, and the cost recovery period is long. In order to extend the cruise industry network, some international cruise companies have shown great enthusiasm for building a cruise terminal in China's sole port or joint venture. Therefore, Tianjin should take appropriate policies to carry out comprehensive cooperation with the international cruise company, and encourage international cruise management companies with strong fund and experience involved in the construction and management of the project, and thus train a number of modern and specialized related cruise service enterprises.

Enhance regional comprehensive strength. The development degree of cruise tourism market in cruise cities plays an important role in the formation and development of cruise cities. Chinese first choice of international cruise home port is Shanghai. It is because of the advantages of Shanghai, including the large population, the huge economic potential and the great development of potential cruise tourism market, Tianjin still has a certain gap. Therefore, Tianjin should further enhance the comprehensive economic strength of the region so as to lay a solid foundation for developing cruise tourism.

Establish efficient management system. Cruise tourism usually involves tourism, transportation, ports, customs, ports and other functional departments, which requires the innovation of the existing management system and the establishment of effective coordination mechanisms and cooperation norms. At the same time, it enables departments to cooperate on a broader basis. For example, the state still adopts the general regulations of entry and exit for the entry and exit of cruise ships and the administration of ports, which leads to access time is too long for cruise passengers and inconvenient access. The expensive fees on berth for Chinese cruise have seriously affected the development of cruise tourism.

Provide preferential policies for cruise tourists. When cruise tourists travel in Tianjin for shopping, they can be given certain preferential policies, and be implemented the policy of tax refund for shopping. This will stimulate the consumption of international tourists in Tianjin, and promote the development of other related industries. We use cruise tourism to promote and promote related industries, forming a multi industry common development of economic phenomena.

Speed up the cultivation of cruise professionals. Some qualified universities in Tianjin can set up a cruise tourism major, so as to train urgently needed senior cruise tourism talents in Tianjin. At the same time, cruise enterprises can train professionals combined with universities, research institutes and government, which was a government led, based on universities and research institutes and funded by enterprises project. Enterprises can also formulate preferential policies, introduce domestic and international cruise tourism management personnel, and actively create conditions to select capable and highly qualified personnel to study in the western countries. Only in this way can we better meet the needs of talents in the industry.

Increase cruise travel publicity. At present, there is still a gap on the income between China and the developed countries. The awareness of tourism consumption in China is relatively weak, and the residents do not have high awareness of the high-end tourist products such as cruise tourism, and the number of tourists taking cruise tours is also low. Therefore, China's cruise tourism market still needs to be cultivated vigorously, and it needs to be guided by extensive publicity to guide residents' consumption. In order to develop the cruise tourism, Tianjin should increase the publicity of cruise tourism, actively participate in the world cruise organization activities, and publicize the 
advantages of Tianjin's development of cruise tourism to international cruise companies, so that the world will fully understand and understand Tianjin. At the same time, we should actively promote Tianjin's urban tourism image in view of the main tourist market, so as to attract more cruise tourists and enhance the competitiveness of Tianjin in the cruise tourism market.

\section{Summary}

With the rapid development of China's economy and the improvement of people's living standard, cruise tourism is bound to be more and more popular among tourists. Tianjin has the basic condition of developing cruise tourism and certain regional advantages, so it has reason to develop cruise tourism. Although there are some constraints and other threats to the port city, Tianjin can combine their own conditions to make full use of advantages and seize the opportunities for development, so that to make up for its weakness and develop the cruise products suitable for consumers and tap the great potential of Tianjin cruise tourism. As a result, this can actively promote the Tianjin cruise tourism towards to the direction of modernization and internationalization.

\section{References}

[1] Huang Ying, Liao Minsheng. Research on Analysis and Countermeasures for Sansha Cruise Tourism Development Status[J]. Travel Overview, 2017, (02): 28-29.

[2] Liu Likui, Jiao Huiyuan. Strategy of Tianjin Cruise Tourism Development from the Perspective of Beijing, Tianjin and Cooperation[J]. Tianjin Economy, 2014, (08): 16-18.

[3] Li Xiaonan. On the Current Situation and Marketing Strategy of Tianjin Cruise Tourism Market[J]. Journal of Jiamusi Institute of Education, 2014, (06): 449-450.

[4] Zhao Yue, Liu Peng. Development status and SWOT analysis of Tianjin Cruise Economy[J]. Port Health Control, 2013, (04): 9-12.

[5] Li Xiaonan. Study on Development Potential of Cruise Tourism in Tianjin[J]. Economic Research Guide, 2013 (17): 198-199+212.

[6] Ni Lishuai. Study on the Evaluation of Interactive Development of Tianjin Cruise Home Port and City[D]. Dalian Maritime University, 2013. 